\title{
Strictly Personal
}

\section{Called as an expert witness}

\author{
JONATHAN SINCLAIR CAREY
}

Last year the $B M \mathcal{F}$ published my first effort to articulate what it was like to be born with microtia-a severe congenital deformity of an ear-and to undergo surgical reconstruction as a child (4 May 1985, p 1348). The account had been difficult to write and see published. Autobiography was combined with principles of medical ethics. I was uncomfortable presenting the personal material. But subsequent results seemed worth while to report.

To my surprise 36 people responded. Letters came from throughout the world-from the United States, Japan, Singapore, and Zimbabwe. Most letters were from plastic surgeons and other physicians with questions or comments about my account, surgical treatment from the patient's perspective, and treatment of children. Several parents wrote about their deformed children, agonising over what to do.

I shared the Personal View with friends and colleagues. They could read about what we never really discuss. One type of reaction was interesting. Some friends and colleagues could not understand why the deformity would bother me. "I never noticed it," they would invariably remark as if that were a compliment. Inevitably the response caused me to roll my eyes. In 35 years of living with the condition I can stand or sit with concealing ease. Yet-to be honest-some tension inevitably remains. If this were their response then how do they identify authentic or legitimate suffering?

Several speaking engagements also resulted from the publication. At one meeting with London plastic surgeons a surgeon declared bluntly after examining my reconstruction, "Let's face it, your results are bad." How cathartic to learn that this emperor really wore no clothes. His naked honesty was appreciated.

A philosophical analysis appeared in the September 1985 issue of the American journal Aesthetic Plastic Surgery. Having published the second article, I considered the topic exhausted. Quite frankly, I had little desire to become the Elephant Man of ears. But an old adage suggests that you should write about what you know. The two studies allowed me to combine my graduate research in medical ethics and theology.

\section{Invitation from Wenatchee}

Yet it was not the last word. Several months later an attorney from outside of Seattle, Washington, telephoned. He had read the $B M \mathcal{F}$ article. He asked if I would serve as an expert witness in a forthcoming trial. His client had sustained serious facial injuries, including the loss of an ear, in a vehicular mishap. Because of my personal and professional concern with ear deformities, he believed this would demonstrate unique expertise in the personal injury lawsuit. My presence would help his case.

I was flown to the United States at the end of November. Several parting conversations with Oxford professors came to mind during

Green College at the Radcliffe Observatory, Oxford OX2 6HG JONATHAN SINCLAIR CAREY, MDIV, STM, theologian the long flight. They agreed on one point: serving as an expert witness would be a gruelling and potentially humiliating experience. A neuropathologist even related that a colleague who had testified had been physically attacked on the stand. Such stories did little to breed confidence.

Arriving in Seattle, a small aircraft then flew me through a blinding snowstorm to the final destination. The plane landed by the small town, hidden and dwarfed by mammoth snowcapped mountains. Somehow I knew that the Green College scarf had never before flapped in the chilly winds of Wenatchee, Washington. Standing in the midst of the ice covered landing field, winds howling, snow everywhere, the mixed emotions that Amundsen and Scott must have felt during their expeditions flowed through me.

Eventually I met the lawyer's client. She timidly removed her discoloured prosthetic ear and exposed the terrible extent of her injuries. At one point she turned to me and asked, "What's it like-I mean to live with?" Her halting, indirect words indicated how terribly alone she had been feeling with her new affliction. Even with long hair to cover the disfigurement, the suffering in her eyes was obvious. She did not want the response, "I never would have noticed."

I testified the second day. Having been a graduate student for four years, working in the confines of my room, it was rather bizarre to be seated four feet from a judge and jury in this viva voce. The attorney asked detailed questions about my professional expertise. Then came the moment. Remember the Phantom of the Opera? The unmasking scene? In this case, the 12 men and women of the jury were invited to stare at the side of my head. When I had testified for two and a half demanding hours, until late afternoon, the judge adjourned the trial for the day.

Five minutes later the judge emerged from his chambers wanting to talk to me. He wondered, based on observations from the bench and touring prisons, if any established corollaries between birth defects and criminal tendencies existed. For 20 minutes we discussed what deprivation or mutilation of part of the human body might suggest about suffering and evil acts.

I would not have imagined that in a west coast courtroom-far from an Oxford common room-such a conversation would occur. I mentioned Thomas Aquinas on sin and birth defects (Summa Theologiae and recited the powerful Shakespearean monologue uttered by the deformed Gloucester in Richard III:

\footnotetext{
"I, that am rudely stamp'd, and want love's majesty

To strut before a wanton ambling nymph;

I, that am curtail'd of this fair proportion,

Cheated of feature by dissembling nature,

Deform'd, unfinish'd, sent before my time

Into this breathing world, scarce half made up,

And that so lamely and unfashionable

That dogs bark at me, as I halt by them."
}

Our discussion concluded with the Danish philosopher Kierkegaard. In Fear and Trembling he comments on Gloucester: "His monologue in the first act of Richard III is more valuable than all those systems of morality which have no idea of the terrors of existence and their explanation." I knew that my own "dissembling 
nature" had certainly influenced my thinking - and feeling-as a moral theologian. I could understand those people feeling imprisoned within a deformed body and seeking revenge on the world-such as Gloucester.

I flew back to England the next day as the trial continued. During the flight the young woman came to mind. Her mother had been in choking sobs during my testimony. I had articulated what her daughter could not. A certain sadness descended. It was one thing to write about an ear in the pages of this medical journal for a professional readership, or to speak to plastic surgeons, but to be examined in a court of law is altogether different. The woman's life would never be the same; and I formally announced the fact.

\section{Unexpected new doors}

When my first Personal View appeared I indicated how vulnerable it made me feel. The publication certainly affected my life. It opened unexpected new doors. Several professional friendships resulted. Receiving 36 letters, some written with painstaking, poignant details, and responding was rewarding. Testifying at a trial 4000 miles away was the most unexpected result. The conversations with the judge and the disfigured woman will remain with me for a long time. For all of these reasons the initial publication was worth the vulnerability in attempting to address Kierkegaard's "terrors of existence and their explanation."

\title{
Insulin and independence
}

\author{
JACK D EASTWOOD
}

Many diabetics seem to experience unnecessary anxiety and disturbance of their normal way of life owing to the difficulty that they find in correctly regulating their insulin dosage and to restrictions imposed on their diet. I have been a diabetic for 60 years and for the past 50 have employed a somewhat unorthodox method of treatment, which I adopted after nearly 10 years of intensive study, much of it experimental and all based on carefully documented observation of my own experience with insulin.

In brief summary, its distinctive feature is that I inject insulin at every mealtime and vary the dose according to the food eaten, instead of basing the treatment on a fixed dose of insulin each morning and then trying to adjust my diet, exercise, etc, to this throughout the next 12 or 24 hours.

\section{The first year}

I was one of the first to benefit from the discovery of insulin. My diabetes was diagnosed in 1925, when I was 13 years old. At that time I was very thin and small and had an inordinate thirst, and I doubt whether my parents needed any other warning signs than these, as the younger of my two elder brothers had died of diabetes six years previously, just before his 12th birthday, after being kept alive for some time by very great restrictions on his diet: the discovery of insulin was tragically too late from his point of view but just in time to save my life. I was taken to a Harley Street specialist and spent three weeks in a nursing home, during which time my diet and insulin requirements were settled. I returned home to be looked after by my parents in accordance with the detailed instructions given to them.

My diet was strictly controlled, especially on the carbohydrate side; for two years all my food was weighed, and no excesses at all were allowed. Much of my food consisted of specially manufactured sugar free brands, so that sugar was entirely replaced by saccharine; the necessary bulk was provided by large quantities of green vegetables. Subcutaneous injections of soluble insulin were given before breakfast and supper each day. I cannot remember exactly what the daily dose was in those earliest days, but I believe that it was about $20 \mathrm{U}$ with the carbohydrate content of my food amounting to about $25 \mathrm{~g}$.

At this stage my knowledge of what was going on was confined to a clear understanding of how important it was to keep to the rules, and to early recognition of the symptoms of an overdose of insulin; reactions of this kind were encouragingly few, and this first year was marked by a rapid and dramatic improvement in the state of my general health and development.

Skipton, North Yorkshire

JACK D EASTWOOD, MA, retired headmaster

Correspondence to: 4 Low Lane, Embsay, Skipton, North Yorkshire BD236SD.

\section{Early study: daily charts}

In 1926, at the age of 14, I won a scholarship to St Paul's School, and as that necessitated travelling to London by train daily and having lunch at an ordinary Lyons restaurant I felt the need to learn more for myself both about diabetes in general and about my own case in particular. I therefore began regularly doing my own insulin injections and urine tests and reading as much as I could on the subject, and it was not long before I was able with considerable accuracy to guess the weight of a normal helping of most of the commonest foodstuffs and to work out the carbohydrate, protein, and fat content of any meal that I ate, realising that it was essential for me to do this if I was ever going to have a meal in a restaurant or, indeed, anywhere other than at home.

This exercise, and the study both on general and on personal grounds that accompanied it, soon became so interesting to me that in March 1929 I decided to start keeping daily charts on which I systematically recorded a wide variety of facts and figures relevant to my life as a diabetic, including exact details of each injection, of the food eaten at every meal, and of the results of urine tests, which I did two or three times each day, together with comments and queries, which I added at the end of some of the more unusual weeks. I continued this practice for six years, almost without a break, and consider therefore that these charts may constitute one of the longest and most detailed diabetic histories in existence. The charts are still in my possession, and I would readily lend them to any responsible person who thinks that they might be of some help or interest to him.

\section{Experiments at Oxford}

In 1931 I went up to Oxford, having won a scholarship to New College, and it was during the next five years while I was there that I learnt most about diabetes and took the first steps towards the less orthodox but, I would submit, not less intelligent method of treatment that had become normal in my case by the time I left university.

I lived a full, normal, and happy life at Oxford for those five years. I usually had breakfast in my own room, consisting of about $65 \mathrm{~g}$ carbohydrate, $12 \mathrm{~g}$ protein, $25 \mathrm{~g}$ fat, and large quantities of green vegetables to make up the bulk which I still needed; these vegetables were, in fact, the only special request I had to make of the college kitchen staff. More often than not I had lunch at an ordinary restaurant (about $10 \mathrm{~g}$ carbohydrate, $40 \mathrm{~g}$ protein, $30 \mathrm{~g}$ fat, and again plenty of green vegetables), and nearly every afternoon I played golf and then had three or four cups of tea (with a little milk). On most evenings I had the normal four course dinner in hall, eating whatever foods were served in the quantities required to provide about $65 \mathrm{~g}$ carbohydrate, $35 \mathrm{~g}$ protein, and $30 \mathrm{~g}$ fat; the accuracy of these calculations I regularly checked by urine tests before going to bed each evening, and I found myself able to make them almost instinctively after about a year. Two insulin injections were given daily, one of $25 \mathrm{U} 30$ minutes before breakfast and one of $35 \mathrm{U} 45$ minutes before dinner. 